\title{
Workshop Penggunaan Media Pembelajaran Berbasis Sampah dan Barang Bekas Bagi Guru MIN TTU
}

\author{
Hermina Disnawati ${ }^{1}$ ), Farly Oktriany Haning2) \\ Pendidikan Matematika, Fakultas Ilmu Pendidikan, Universitas Timor, Indonesia ${ }^{1,2)}$ \\ Pos-el:enudisna@yahoo.com ${ }^{1)}$; farlyoktriany.haning@ gmail.com ${ }^{2)}$
}

\begin{abstract}
Abstrak
Permasalahan pokok di Madrasah Ibtidayah Negeri (MIN) TTU-Kefamenanu yang menjadi mitra pengabdian ini adalah: (i) belum tersedianya alat peraga matematika di sekolah mitra; (ii) belum pernah diselenggarakan kegiatan workshop tentang penggunaan alat peraga matematika di sekolah mitra. Metode pelaksanaan yang digunakan dalam pengabdian ini adalah ceramah, demonstrasi, praktek langsung, diskusi dan penugasan. Adapun alat peraga yang digunakan antara lain: Mistar Bilangan, Kartu Positif Negatif, Puzzle FPB dan KPK, Magic Square, Perkalian Kanada, Congklak Penjumlahan, Tabel Cayley, Ular Tangga Aljabar, Menara Hanoi dan Tangram. Alat peraga matematika ini terbuat dari sampah dan barang bekas. Pelaksanaan pengabdian selama 3 hari dengan rincian satu hari workshop dengan peserta 20 guru dan dua hari praktek penggunaan alat peraga dengan peserta 80 siswa kelas IV, V dan VI. Hasil evaluasi pengabdian menunjukkan bahwa i) 33,33\% peserta sangat setuju dan $66,67 \%$ peserta workshop setuju bahwa materi workshop terorganisasi dengan baik dan alat peraga yang digunakan sesuai dengan materi pembelajaran di sekolah dasar, alat peraga menarik dan membantu siswa dalam belajar sambil bermain; ii) $80 \%$ peserta setuju dan $20 \%$ sangat setuju bahwa panduan praktik penggunaan alat peraga dengan LKS yang disediakan dapat dimengerti dengan baik.
\end{abstract}

Kata Kunci: Alat Peraga Matematika, Sampah dan Barang Bekas

\begin{abstract}
The main problems in primary school of MIN TTU- Kefamenanu are: (i) the unavailability of mathematics manipulatives for helping teacher and students learn meaningfully; (ii) there has never been a workshop about mathematics manipulatives. The method that used in this workshop were: lectures, demonstration, direct practices, discussion, and assignment. The manipulatives that are used are Numeral Ruler, Positives-Negatives (posinega) Cards, Least Common Multiple (LCM) and Greatest Common Factor (GCF) Puzzle, Magic Square, Canadian Multiplication, Congklak, Cayley Tables, Math Snake-Ladders Game, Hanoi Tower and Tangram. All of these manipulatives were made from garbage and used goods. The workshop was held in 3 days which was the first day focus on 20 teachers as the main participants and the next two days was focus on practice of using the manipulatives with involved 80 students and teachers of grade $4^{\text {th }}, 5^{\text {th }}$ and $6^{\text {th }}$. Participants were asked to fill out the questionnaire. The results showed that i) $33.33 \%$ of participants strongly agreed and $66.67 \%$ of workshop participants agreed that the workshop material was well organized and the workshop content appropriate with curriculum in elementary schools, and the manipulatives was interesting for students and helping them to learn while playing; ii) $80 \%$ of participants agreed and $20 \%$ strongly agreed that the practice guidelines for using mathematics manipulatives with worksheets was well understood.
\end{abstract}

Keywords :Mathematics manipulatives, Garbage and used good 


\section{PENDAHULUAN}

Madrasah Ibtidayah Negeri TTU adalah satu-satunya madrasah ibtidayah di Kabupaten Timor Tengah Utara. Sekolah ini bermula dari sekolah swasta dengan nama MI Nurul Falah yang dibangun oleh Yayasan Nurul Falah. Sejak tahun 2005 pengelolaan MI Nurul Falah diambil alih oleh pemerintah dan namanya diubah menjadi menjadi Madrasah Ibtidayah Negeri TTU-Kefamenanu. Sudah hampir 15 tahun menjadi negeri, sekolah ini masih terus berkembang dan sekarang memiliki 17 guru dan 3 tenaga kependidikan. Namun, masih kekurangan guru dengan latar belakang pendidikan guru SD sehingga guru agama diharuskan menjadi guru kelas yang mengajar pelajaran di kelas secara tematik. Lebih lanjut, kurikulum 2013 edisi revisi 2018 sudah memisahkan pelajaran matematika untuk kelas tinggi dengan pelajaran tematik lainnya. Di sekolah ini mata pelajaran matematika untuk kelas tinggi di sekolah mitra di ajar oleh guru kelas tamatan PGSD dengan peminatan kimia dan fisika bukan matematika.

Para guru juga mengakui bahwa mereka masih kesulitan dalam menerapkan pembelajaran berbasis kurikulum 2013 (K13) karena kurangnya kemampuan untuk membuat aktifitas belajar dengan bantuan alat peraga matematika. Mereka cenderung tidak mengetahui cara penggunaan alat peraga sebagai alat bantu dalam belajar sebab belum pernah ada kegiatan dari pihak sekolah maupun luar sekolah yang membantu mereka.

Alat peraga matematika yang digunakan dalam pembelajaran dapat meningkatkan hasil belajar siswa di sekolah dasar berdasarkan hasil penelitian dari Dahniar, I dkk. (2017); Crismono (2017); Hidayah, I (2018). Namun ketersediaan alat peraga yang murah sulit didapatkan dan juga kurangnya keterampilan guru dalam mengajar menggunakan alat peraga membuat guru lebih memilih mengajar tanpa alat peraga. Jika ada materi tematik yang berkaitan dengan alat peraga dibiarkan saja.

Berdasarkan analisis situasi, ditulis secara ringkas permasalahan pokok pada mitra yaitu : (i) belum tersedianya alat peraga matematika di sekolah mitra; (ii) guru belum terampil menggunakan alat peraga sebab guru-guru yang mengajar pelajaran matematika bukanlah guru dengan latar belakang pendidikan matematika atau pendidikan guru SD peminatan matematika; (iii) belum pernah diselenggarakan kegiatan workshop/ pelatihan/ lokakarya tentang penggunaan alat peraga matematika di sekolah mitra.

Permasalahan yang ada membuat pengabdi merasa perlu melakukan workshop penggunaan media pembelajaran matematika berdasarkan kurikulum 2013 bagi guru-guru di MIN TTU. Target luaran dari kegiatan pengabdian ini adalah i) terbuatnya alat peraga matematika berbasis sampah dan barang bekas, ii) para guru mengenal, mengetahui dan memiliki pemahaman yang baik tentang pembelajaran menggunakan media pembelajaran matematika, iii) keterampilan guru dalam mengajar menggunakan media pembelajaran matematika berdasarkan kurikulum 2013 menjadi lebih maksimal. Selain itu, di lingkungan sekitar dapat ditemukan beberapa jenis sampah seperti kardus bekas, papan tripleks bekas, kalender bekas, botol dan gelas air minum kemasan, dan sebagainya. Dari hasil mengamati, muncul ide untuk membuat sampah yang sudah tidak bermanfaat menjadi sesuatu yang berguna bagi pembelajaran matematika berupa alat peraga matematika yang terbuat dari sampah dan barang bekas. 


\section{METODE}

Secara umum pengabdian ini dilaksanakan di Madrasah Ibtidayah Negeri (MIN) TTU selama bulan Juli 2018 hingga September 2018. Proses pelaksanaan pengabdian terbagi dalam tiga tahapan yaitu persiapan, pelaksanaan dan evaluasi.

Pada tahap persiapan pengabdi melakukan: koordinasi dan diskusi dengan pihak sekolah, identifikasi alat peraga matematika yang sesuai dengan materi kurikulum 2013 di SD, persiapan Lembar Kerja Siswa (LKS) yang sesuai dengan alat peraga dan materi SD, persiapan materi tentang Kurikulum 2013 dan media pembelajaran. Selanjutnya, pelaksanaan pengabdian di MIN TTU -Kefamenanu selama 3 hari yaitu tanggal 25 Agustus 2018, dilanjutkan 27-28 Agustus 2018. Bentuk pelaksanaan pengabdian hari pertama berupa workshop untuk 20 guru. Sedangkan pada hari kedua dan ketiga dilakukan praktek mengajar di kelas tinggi dengan total peserta 80 siswa menggunakan alat peraga matematika yang terbuat dari sampah dan barang bekas.

\section{HASIL DAN PEMBAHASAN}

Pembahasan hasil pengabdian ini dijelaskan berdasarkan tahapan kegiatan yang dilakukan sebagai berikut.

\section{Persiapan}

Pada proses persiapan, pertama-tama pengabdi melakukan survey awal dan mendapati bahwa di sekolah mitra membutuhkan workshop tentang media pembelajaran matematika. Selanjutnya pengabdi mempersiapkan alat peraga yang sesuai dengan pembelajaran matematika kurikulum 2013. Selain itu, pengabdi juga mempersiapkan materi yang disampaikan pada workshop. Alat peraga yang dipilih untuk digunakan dalam workshop ada 10 jenis alat peraga yaitu Mistar Bilangan, Kartu Positif Negatif, Congklak Penjumlahan, Puzzle FPB dan KPK, Tabel Cayley, Tangram, Magic Square, Perkalian Kanada, Ular Tangga Aljabar dan Menara Hanoi. Bahan baku utama dalam pembuatan alat-alat peraga ini adalah kayu bekas dan tripleks yang sudah tidak terpakai, kardus dan kalender bekas, gelas dan botol air minum kemasan bekas, dan beberapa barang bekas lainnya.

Mistar Bilangan, Kartu Positif Negatif dan Congklak Penjumlahan sangat cocok untuk materi tentang operasi penjumlahan dan pengurangan bilangan bulat. Untuk membantu siswa kelas tinggi memahami Faktor Persekutuan Terbesar dan Kelipatan Persekutuan Terkecil dibuat alat peraga Puzzle FPB dan KPK. Siswa juga tertolong memahami kelipatan bilangan melalui alat peraga Perkalian Kanada dan Tabel Cayley. Alat peraga Tangram membantu siswa memahami konsep geometri yaitu bangun datar segitiga dan segiempat. Alat peraga lainnya dapat digunakan untuk belajar sambil bermain yaitu Menara Hanoi, Ular Tangga Aljabar, dan MagicSquare (Persegi Ajaib). Alat peraga yang dihasilkan ini sama seperti kriteria alat peraga yang baik menurut Sundayana (dalam Mariyah, 2017:3) diantaranya tahan lama, menarik, sederhana, sesuai dengan konsep materi, menjadi dasar tumbuhnya konsep abstrak bagi anak, serta menjadikan belajar menjadi aktif dan mandiri.

\section{Pelaksanaan}


Pada hari pertama pelaksanaan pengabdian, jumlah peserta workshop sebanyak 20 orang guru. Kegiatan hari pertama dilaksanakan pada tanggal 25 Agustus 2018 dan dibuka secara resmi oleh Kepala Sekolah MIN TTU. Pada sesi pertama pengabdi memberi materi tentang kurikulum 2013 dan media pembelajaran matematika, termasuk media pembelajaran yang dapat dibuat dari sampah dan barang bekas sesuai dengan konteks dan konten materi yang diajarkan. Materi yang disajikan meliputi: 1) Urgensi penggunaan media pembelajaran di Sekolah Dasar; 2) Jenis-jenis media pembelajaran matematika; 3) Jenis alat peraga matematika yang digunakan; 4) Simulasi penggunaan alat peraga matematika dalam pembelajaran matematika.

Pada sesi yang kedua dilakukan simulasi penggunaan alat peraga matematika sekaligus praktek sebagai guru model dan para guru berperan sebagai siswa. Sebagai peserta guru-guru dibagi menjadi 5 kelompok dengan jumlah peserta masing-masing kelompok adalah 4 orang. Pada sesi ini peserta sangat antusias dan tertarik untuk mengerjakan LKS yang disediakan oleh pengabdi menggunakan media pembelajaran yang disampaikan pada sesi pertama. Setiap alat peraga yang digunakan dihubungkan dengan materi ajar siswa dalam bentuk LKS sehingga para guru menganggap proses belajar mengajar dengan bantuan alat peraga sangat membantu mereka memahami konsep matematika dengan cepat. Setelah sesi kedua berakhir, para guru diberi kesempatan untuk mempersiapkan praktek penggunaan alat peraga yang ada di kelas tinggi pada hari berikutnya.

Hari kedua dan ketiga pengabdian dilaksanakan pada tanggal 27-28 Agustus 2018 yaitu: pengabdi melakukan praktek penggunaan media pembelajaran di kelas IV, V dan VI MIN TTU Kefamenanu. Praktek ini dilakukan bersama dengan guru kelas yang telah mengikuti workshop pada hari sebelumnya. Total peserta siswa kelas tinggi yang mengikuti kegiatan praktek pengabdian adalah 80 orang yang terdiri dari Siswa kelas IV MIN TTU berjumlah 28 orang. Siswa kelas V sebanyak 25 orang dan siswa kelas VI berjumlah 27 orang.

Kegiatan praktek hari pertama dan kedua berjalan lancar sesuai dengan waktu perencanaan. Siswa sangat antusias dan tertarik dalam pembelajaran matematika dengan menggunakan alat peraga yang merangsang daya pikir kreatif dan menambah rasa ingin tahu mereka. Siswa lancar mengerjakan LKS operasi penjumlahan dan pengurangan bilangan bulat dengan bantuan alat peraga Mistar Bilangan, Kartu Positif Negatif dan Congklak Penjumlahan. Sedangkan sebagian siswa dalam kelas tinggi belum mampu membedakan faktor bilangan dan kelipatan bilangan, sehingga mereka sangat terbantusaat menggunakan alat peraga Puzzle FPB dan KPK, Perkalian Kanada dan Tabel Cayley.

Selanjutnya, sifat-sifat geometri dari bangun datar segitiga dan segiempat dipelajari oleh siswa sambil menyusun block bangun datar menjadi macam-macam bentuk yaitu rumah, orang, kuda, dan beberapa bentuk lagi. Pelajaran yang disampaikan menggunakan alat peraga Tangram menjadi lebih mudah karena siswa melihat secara langsung bentuk bangun datar yang ada. Alat peraga sederhana lainnya digunakan untuk belajar sambil bermain yaitu Menara Hanoi, Ular Tangga Aljabar, dan MagicSquare (Persegi Ajaib). Alat-alat peraga ini menjadikan siswa belajar menjadi aktif dan mandiri serta mencari strategi terbaik agar bisa tercapai tujuan permainan. Bahkan masih ada siswa yang ingin terus dilanjutkan walaupun waktu sudah selesai. Pada akhirnya kegiatan pengabdian berupa workshop praktek 
penggunaan alat peraga berbasis sampah dan barang bekas untuk guru-guru di MIN TTU dapat dikatakan berhasil dilaksanakan dengan baik dan lancar serta tujuan pengabdian juga tercapai.

\section{Evaluasi}

Hasil evaluasi pelaksanaan kegiatan pengabdian kepada masyarakat :

1. Kehadiran dan tingkat partisipasi peserta melalui presensi kehadiran adalah $100 \%$

2. Berdasarkan jadwal pelaksanaan, serta ketepatan waktu pelaksanaan, kegiatan pengabdian ini telah terlaksana dengan baik, sesuai yang di rencanakan.

3. Pada akhir acara para peserta memperoleh wawasan baru tentang media pembelajaran matematika dan alat peraga matematika berupa Mistar bilangan, Kartu Positif Negatif, puzzle FPB dan KPK, Tangram, Tabel Cayley, Ular Tangga Aljabar, Congklak Penjumlahan, Perkalian Kanada, Menara Hanoi, dan MagicSquare

Berdasarkan angket evaluasi kegiatan pengabdian kepada masyarakat diperoleh evaluasi

1. Sebanyak $33,33 \%$ peserta sangat setuju dan $66,67 \%$ peserta workshop setuju bahwa materi workshop terorganisasi dengan baik dan alat peraga yang digunakan cocok dan sesuai dengan materi pembelajaran di sekolah dasar, alat peraga menarik dan membantu siswa belajar sambil bermain, merangsang daya pikir dan rasa ingin tahu siswa.

2. Sebanyak $80 \%$ peserta setuju dan $20 \%$ sangat setuju bahwa panduan praktik penggunaan alat peraga dengan LKS telah tersedia dan dimengerti dengan baik.

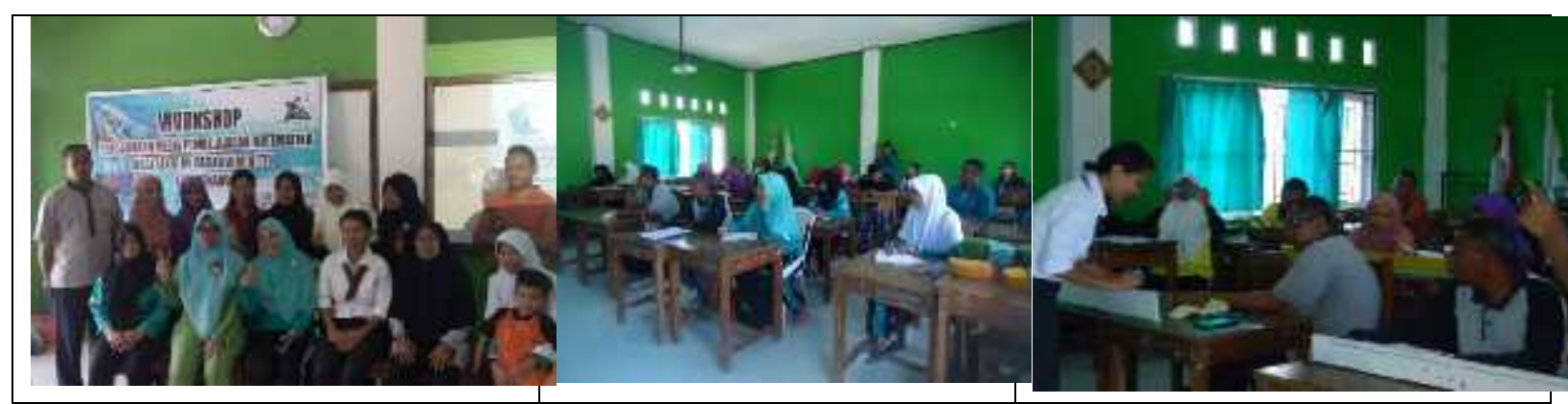

Gambar 1. Pemaparan materi oleh pembicara

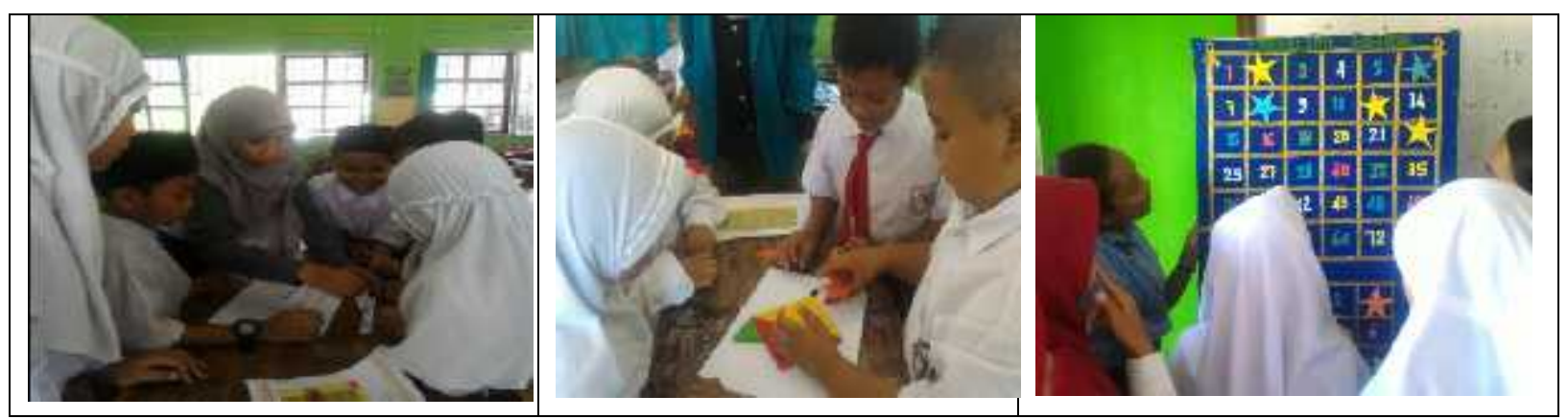




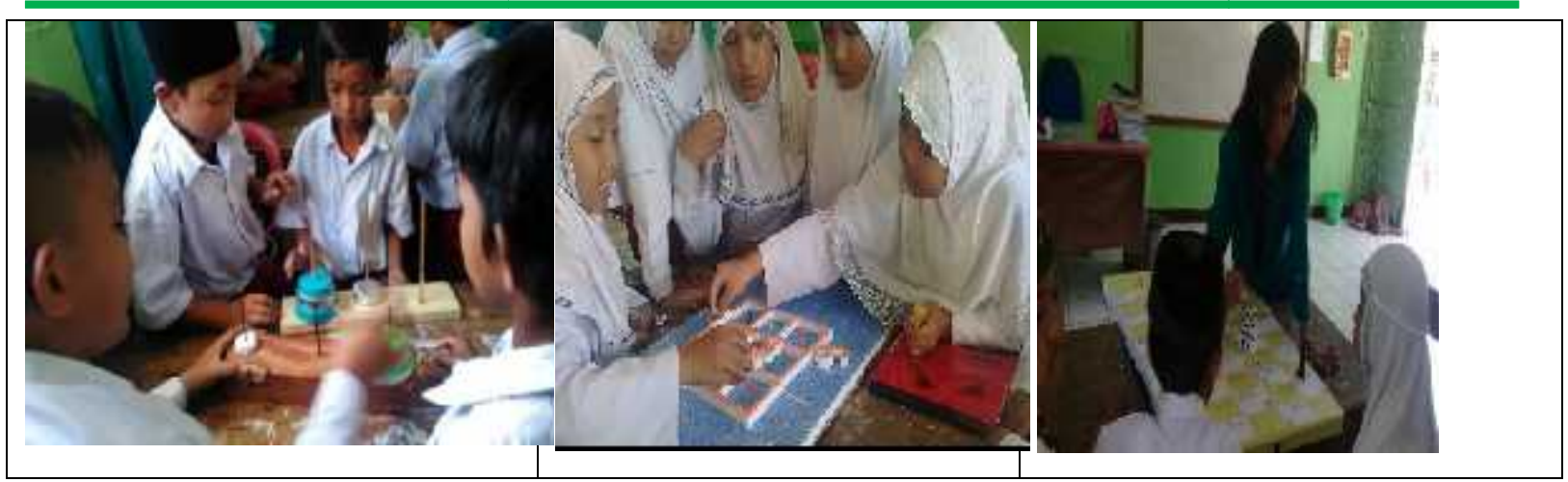

Gambar 2. Proses praktek penggunaan alat peraga pada pembelajaran matematika di kelas-kelas tinggi oleh pengabdi dan guru

\section{SIMPULAN DAN SARAN}

Adapun yang dapat disimpulkan dari kegiatan pengabdian ini adalah:

1. Telah dihasilkan alat peraga matematika yang dapat membantu guru SD dalam pembelajaran di kelas.

2. Para guru mengenal, mengetahui dan memiliki pemahaman yang baik tentang pembelajaran menggunakan media pembelajaran matematika terbukti dengan praktek yang dilaksanakan di kelas.

3. Keterampilan guru dalam mengajar menggunakan media pembelajaran matematika berdasarkan kurikulum 2013 menjadi lebih maksimal, terutama menggunakan media pembelajaran yang berbasis sampah dan barang bekas.

4. Siswa sangat antusias dan tertarik dalam pembelajaran matematika yang menggunakan alat peraga yang merangsang daya pikir kreatif dan menambah rasa ingin tahu mereka.

Saran terkait dengan pengabdian yang dilakukan yaitu pengabdian ini masih terbatas pada penerapan media pembelajaran untuk materi di sekolah dasar sehingga disarankan pada pengabdian selanjutnya dipraktekan untuk materi SMP dan SMA. Selain itu, dapat dicoba penelitian berupa pengujian hasil belajar siswa menggunakan alat peraga yang dihasilkan.

\section{UCAPAN TERIMA KASIH}

Ucapan terimakasih ditujukan kepada Lembaga Penelitian dan Pengabdian pada Masyrakat (LPPM) Universitas Timor sebagai pemberi dana pengabdian bagi masyarakat dari dana Tahun Anggaran 2018

\section{DAFTAR PUSTAKA}

Chrismono, P.C. "Penggunaan Media dan Sumber Belajar Dari Alam Sekitar dalam Pembelajaran Matematika”. JurnalGammath,2.2.(2017). Web. Mei 2018

Dahniar, I Nyoman Murdiana, Sukayasa. "Penggunaan Alat Peraga Untuk Meningkatkan Hasil Belajar Siswa Kelas 1 SD Negeri 6 Tolitoli dalam Menyelesaikan Soal Cerita Tentang Penjumlahan dan Pengurangan". Jurnal Kreatif Tadulako Online. 4.3.(2016). Web. Mei 2018 
Hidayah, Isti. "Pembelajaran Matematika Berbantuan Alat Peraga Manipulatif Pada Jenjang Pendidikan Dasar dan Gerakan Literasi Sekolah". PRISMA, Prosiding Seminar Nasional Matematika.1.1.(2018) : 1-11. Web. Mei 2018

Mariyah, Christiyanti Aprinastuti, Brigita Erlita Tri Anggadewi. "Pengembangan Alat Peraga untuk Meningkatkan Kemampuan Belajar Matematika pada Anak dengan ADHD”. Prosiding Temu Ilmiah X Ikatan Psikologi Perkembangan Indonesia. (2017) : 240-250. Web. Mei 2018 